\title{
Is Luwak Coffee a Monopolistic Competition Product?
}

Luwak coffee or Kopi Luwak is one unique coffee that is made from Asian Palm Civet's feces. Asian Palm Civet is called Luwak in Indonesia. The coffee beans are being fermented in its stomach, and that is how Luwak coffee gets its unique flavor. Coffee Luwak was found in the period of cultuurstelsel which is the period where local people of Indonesia were not allowed to pick coffee fruits. Because of that, people notice the undigested coffee seeds in Luwak's feces and started to use it for their own (Pratono \& Radjamin, 2012).

Years ago, Luwak coffee's development in product and market was under VOC and had experienced competitions with other countries in the World Coffee Market. Based on the history, VOC didn't have the market power to conquer the price of coffee in the World Coffee Market, or in the competition itself. Market power determines the kind of market competition in a country or between countries (Cupian \& Abduh, 2017). The low market power of coffee Luwak and other coffee markets or products in the World Coffee Market, causing a fierce market competition. And because of the low market power of Luwak coffee in the World Coffee Market, the market competition can be defined as monopolistic competition. This is because many kinds of coffee are provided in the market.

The local market for coffee has grown wide recently, and it has been one of the most popular drinks nowadays. The market power of coffee, especially Luwak coffee now has increased rather than years ago, and causing market competition to decrease (Chang, Liang, \& Yu, 2018). The increase in market power doesn't mean that Luwak coffee is monopolizing the market. Because Luwak coffee still has competitors from the coffee market and other drink-based product markets. A monopoly is the ability of a company or a firm to control the price of a certain product. If Luwak coffee wants to monopolize the coffee market, it must have big market power, high market barrier for other coffee enterprises to enter, and also low market concentration (Sun, Jing, Zhao, \& He, 2017). The idea is, Luwak coffee can monopolize the market if the producer of Luwak coffee chooses to develop his or her business in a certain place where there are no Luwak coffee in the market. 


\section{Bibliography}

Chang, H. Y., Liang, L. H., \& Yu, H. F. (2018). Marketpower, competition and earnings management: accrual-based activities. Journal of Financial Economic Policy, 11, 368-384.

Cupian, \& Abduh, M. (2017). Competitive condition and market power of Islamic banks in Indonesia. International Journal of Islamic and Middle Eastern Finance and Management, 10, 77-91.

Pratono, A. H., \& Radjamin, I. p. (2012). Kopy Luwak: a conservation strategy for global market. Emerald Emerging Markets Case Studies, 2, 1-5.

Sun, B., Jing, W., Zhao, X., \& He, Y. (2017). Research on market power and market structure A direct measure of market power of internet platform enterprises. International Journal of Crowd Science, 1, 210-222. 